\title{
Redox dynamics of sulphur with Ni/GDC anode during SOFC operation at mid- and low-range temperatures: An operando S K-edge XANES study
}

\author{
G. Nurk ${ }^{\mathrm{a}, *}$, T. Huthwelker ${ }^{\mathrm{c}}$, A. Braun ${ }^{\mathrm{b}}$, Chr. Ludwig ${ }^{\text {d,e }}$, E. Lust ${ }^{\mathrm{a}}$, R.P.W.J. Struis ${ }^{\mathrm{d}}$ \\ ${ }^{a}$ Institute of Chemistry, University of Tartu, 14a Ravila Str., 50411 Tartu, Estonia \\ ${ }^{\mathrm{b}}$ Laboratory for High Performance Ceramics, Empa, Swiss Federal Laboratories for Materials Science and Technology, CH-8600 Dübendorf, Switzerland \\ ${ }^{\mathrm{c}}$ Swiss Light Source (SLS), Laboratory for Catalysis and Sustainable Chemistry (LSK), Paul Scherrer Institut, CH-5232 Villigen PSI, Switzerland \\ ${ }^{\mathrm{d}}$ Laboratory for Bioenergy and Catalysis (LBK), Paul Scherrer Institut, CH-5232 Villigen PSI, Switzerland \\ e École Polytechnique Fédérale de Lausanne (EPFL-ENAC-IIE), 1015 Lausanne, Switzerland
}

\section{H I G H L I G H T S}

- An operando SOFC anode S-poisoning XAS experiment at $550{ }^{\circ} \mathrm{C}$ to $250{ }^{\circ} \mathrm{C}$ was performed.

- S K-edge XANES spectral information at Ni/GDC outer surface was collected.

- Intermediates with different sulphur oxidation states $(6+, 4+, 0,2-)$ were observed.

- Proportion of oxidation states changed as a function of temperature. - Differences between TD calculations and XAS information were observed and discussed.

\section{A R T I C L E I N F O}

\section{Article history:}

Received 12 July 2012

Received in revised form

12 February 2013

Accepted 28 March 2013

Available online 18 April 2013

\section{Keywords:}

Sulphur poisoning

Ni-GDC

SOFC

XANES

S K-edge

In situ
G R A P H I C A L A B S T R A C T
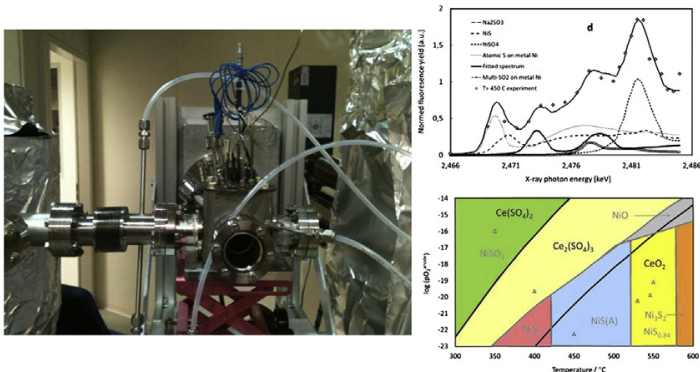

\begin{abstract}
A B S T R A C T
Sulphur poisoning of nickel-based solid oxide fuel cell (SOFC) anode catalysts is a well-documented shortcoming, but not yet fully understood. Here, a novel experiment is demonstrated to obtain spectroscopic information at operando conditions, in particular the molecular structure of sulphur species in the sulphur K-shell X-ray absorption near edge structure (XANES) region for a SOFC anode under realistic operando conditions, thus, with the flux of $\mathrm{O}^{2-}$ from cathode to anode. Cooling from $T=550{ }^{\circ} \mathrm{C}$ stepwise down to $250^{\circ} \mathrm{C}, 5 \mathrm{ppm} \mathrm{H}_{2} \mathrm{~S} / \mathrm{H}_{2}$ reacting with Ni-gadolinium doped ceria (GDC) anode resulted in several sulphur species in different oxidation states $(6+, 4+, 0,-2)$ and in amounts being at a minimum at high temperature. According to sulphur speciation analysis, the species could either relate to $-\mathrm{SO}_{4}^{2-}$ or $\mathrm{SO}_{3}(\mathrm{~g}),-\mathrm{SO}_{3}^{2-}$ or $\mathrm{SO}_{2}(\mathrm{~g}), \mathrm{S}_{2}(\mathrm{~g})$ or surface-adsorbed $\mathrm{S}$ atoms, and, Ni or Ce sulphides, respectively. The coexistence of different sulphur oxidation states as a function of temperature was analysed in the context of thermodynamic equilibrium calculations. Deviations between experimental results and calculations are most likely due to limitations in the speed of some intermediate oxidation steps as well as due to differences between stoichiometric $\mathrm{CeO}_{2}$ used in calculations and partially reduced $\mathrm{Ce}_{0.9} \mathrm{Gd}_{0.1} \mathrm{O}_{2-\delta}$.
\end{abstract}

(c) 2013 Elsevier B.V. All rights reserved.

\footnotetext{
* Corresponding author. Tel.: +372 7 375164; fax: +372 7375264

E-mail address: gunnar.nurk@ut.ee (G. Nurk).
}

\section{Introduction}

Solid oxide fuel cells (SOFC) are promising energy converters with high electrical efficiency (from 45 to $65 \%$ based on lower heating value), fuel flexibility (can oxidise virtually any fuel from 
hydrogen to hydrocarbons up to carbon) and environmental friendliness. To reduce thermal degradation of system components, system costs and radiative heat transfer and to increase the speed of start-up and shut-down cycles, attempts have been made to decrease the operating temperature of SOFC from high temperature at $T=900{ }^{\circ} \mathrm{C}$ to intermediate temperature (IT) between $T=500-750{ }^{\circ} \mathrm{C}[1,2]$ and even to temperatures as low as $T=350{ }^{\circ} \mathrm{C}[3,4]$. In addition to systems doped with noble metals such as Pt and Pd, until now the best electrocatalytic performance for IT-SOFC application was achieved with Ni-based catalysts. But Ni-based SOFC anode catalysts have some weaknesses when operating at intermediate temperature region such as coke formation (when operating on hydrocarbon fuels) and intolerance against some inorganic impurities [5-8]. Particular attention has been paid to sulphur poisoning, because most fuels contain sulphur and the complete removal of it is a costly process. The majority of sulphur poisoning studies have been carried out on $\mathrm{Ni}-$ YSZ (yttrium stabilized zirconia) SOFC anode at elevated working temperatures $\left(T=700-900{ }^{\circ} \mathrm{C}\right)[9-18]$. Only few studies examine sulphur poisoning of Ni-gadolinium doped ceria (GDC) anodes at intermediate temperature region [13,19-23] and the influence of chemical composition of ceramic phase on the poisoning process of $\mathrm{Ni}$-cermet electrodes [24-26]. In good agreement with thermodynamics $[9,20]$ and calculations based on density functional theory (DFT), [27] it has been demonstrated in several electrochemical studies that the extent of sulphur poisoning is a function of temperature, oxygen partial pressure and sulphur concentration as well as chemical nature of fuel and anode material [28-30]. Several studies have demonstrated that there is an initial reversible (or partially reversible) degradation step during the very first minutes when the anode is exposed to $\mathrm{H}_{2} \mathrm{~S}[9,12,31]$, followed by a slow, but continuous, non-reversible decrease of electrode performance $[9,12,31]$. First, rapid decrease of electrochemical performance is likely caused by adsorption of sulphur species at electrode and concomitant blocking of the socalled three-phase-boundary (TPB) for hydrogen oxidation $[9,12]$. There is some consensus about the first step of poisoning, but there are several significantly different if not controversial views about the second, slower step. Some authors are supporting the idea that slow degradation is caused by the formation of volatile $\mathrm{Ni}_{x} \mathrm{~S}_{y}$ phase, which causes restructuring and degradation of electrode structure $[14,15,27]$. Sasaki et al. proposed that blocking of hydrogen diffusion to the TPB caused by sulphur adsorption leads to the oxidation of $\mathrm{Ni}$ at TPB interface, causing depletion of active sites [9]. Slow decline in performance might also be caused by adsorption of sulphur on nickel surface grains which are more difficult to access, such as pores with bottlenecks [14], or, because of surface reconstruction or recrystallization of nickel grains from catalytically more active into catalytically less active crystallographic form [14], or, because of bulk phase diffusion of sulphur penetrating into $\mathrm{Ni}$ grains [14]. One possible reason of slow degradation could be the formation of $\mathrm{Ce}_{2} \mathrm{O}_{2} \mathrm{~S}$ as well as $\mathrm{Ce}\left(\mathrm{SO}_{4}\right)_{2}$ at relatively low $\mathrm{H}_{2} \mathrm{~S}$ concentrations in reaction with nonstoichiometric $\mathrm{CeO}_{n}(n<2)$, because reduced or doped ceria exhibits significantly larger affinity for $\mathrm{H}_{2} \mathrm{~S}$ compared to $\mathrm{CeO}_{2}$ used in theoretical calculations [20,32]. Thus, while there is some information about changes in electrical performance and degradation of electrode structure caused by sulphur at different conditions, there is no comprehensive explanation of the physico-chemical mechanisms which ultimately constitute sulphur poisoning.

\subsection{Motivation and goal}

Different studies have proposed and supported experimentally the idea that the release of sulphur from SOFC electrode might take place through the oxidation of sulphur $[10,18,22,23,29]$, which premises the presence of oxidised particles or intermediates at the anode surface. But, up to now, spectroscopic measurements with X-ray photoelectron spectroscopy (XPS), X-ray absorption spectroscopy (XAS), or, Raman microspectroscopy either obtain information from SOFC anode surface in the presence of $\mathrm{H}_{2} \mathrm{~S}, \mathrm{H}_{2}$, and, possibly even heat, or ex-situ and under postmortem conditions $[14,15,22,33]$. The molecular structure of sulphur compounds has been studied with sulphur K-shell edge Xray absorption spectroscopy in various fields of application, particularly in relation to fossil fuels, such as sulphur in coal [34], sulphur in residual oil fly ash [35] and heterogeneous catalysis [36]. High temperature oxidation and reduction studies [34] and catalysis studies [36] have also been made recently with in-situ or operando sulphur XAS, for example. Sulphur as the ligand ion is also of interest in connection with metal ions [37] and could in future studies open up new opportunities for the understanding and quantification of electronic transport processes in SOFC anodes, where newly formed $\mathrm{Ni}-\mathrm{S}$ compounds are subject to exchange interactions, in analogy to $3 \mathrm{~d}$ metal oxides at SOFC cathodes, for example [38,39]. Latter would constitute an extension of sulphur XAS from molecular structure and chemical speciation of sulphur motifs towards electronic structure, valence band and electronic transport properties of aged SOFC anodes. However, so far, there are no spectroscopic experiments made operando under realistic SOFC anode operation conditions with oxide ion flux from cathode to anode or under electrochemical polarization of the anode. And, when it comes to study of the nickel-sulphur chemistry in detail, we realize that Ni K-edge XAS is less informative than S K-edge XAS [40], particularly because the sulphur K-edge spectra provide a very detailed picture about the molecular structure of the various sulphur species being formed on the anode during typical SOFC operation. Therefore, the present study demonstrates a novel powerful approach with sulphursensitive XAS under operando SOFC conditions for studying processes during sulphur poisoning of an IT-SOFC dedicated electrochemical element.

\section{Experiments and methods}

\subsection{Preparation of SOFC single cell assembly}

The SOFC single cell assemblies tested in this study were typical electrolyte (GDC) supported planar fuel cells with rectangular shape, which were made befitting with the XAS cell compartments. Supporting electrolyte pellets were made from $\mathrm{Ce}_{0.9} \mathrm{Gd}_{0.1} \mathrm{O}_{2-\delta}$ (GDC) powder with $S_{\text {BET }}=19.9 \mathrm{~m}^{2} \mathrm{~g}^{-1}$ (NexTech Materials) pressed at $20 \mathrm{MPa} \mathrm{cm} \mathrm{cm}^{-2}$ and sintered at $1773 \mathrm{~K}$ for $10 \mathrm{~h}$. The electrolyte supported cell configuration was used because of better compatibility with the gas sealing concept used. The anode layer was screen printed onto the sintered electrolyte pellet by applying commercial NiO-GDC ink (Fuel Cell Materials) through 200 mesh screen and fired at $1350{ }^{\circ} \mathrm{C}$ for $3 \mathrm{~h}$ with heating and cooling rates of $2.5 \mathrm{~K} \mathrm{~min}^{-1}$. The choice of sintering temperature was based on the results of our previous studies [41]. Cathode powder was prepared by nitrate solution thermal combustion method using $\mathrm{La}(\mathrm{N}-$ $\left.\mathrm{O}_{3}\right)_{3} \cdot 6 \mathrm{H}_{2} \mathrm{O}, \mathrm{Sr}\left(\mathrm{NO}_{3}\right)_{2} \cdot 6 \mathrm{H}_{2} \mathrm{O}$ (both from Aldrich, 99.9\%) and $\mathrm{Co}(\mathrm{N}-$ $\left.\mathrm{O}_{3}\right)_{2} \cdot 6 \mathrm{H}_{2} \mathrm{O}(98 \%$, Riedel de Haën $)$ as precursors for $\mathrm{La}_{0.6} \mathrm{Sr}_{0.4} \mathrm{CoO}_{3-\delta}$ cathode powder and glycine (99.9\%, Sigma-Aldrich) as a reducing agent. A detailed description of the experimental procedure can be found from Lust et al. [41]. Finally the cathode paste was deposited onto a GDC electrolyte pellet by screen printing followed by $5 \mathrm{~h}$ sintering at $1110{ }^{\circ} \mathrm{C}$ with heating and cooling rates of $2.5 \mathrm{~K} \mathrm{~min}^{-1}[42]$. 


\subsection{Design and electrochemical testing of operando SOFC-XAS cell}

An in situ reaction cell (for use with hard X-rays), which had been constructed at Paul Scherrer Institute, followed the design of Grunwaldt (KIT, Germany) [43], was adapted by us into a SOFCdedicated XAS cell suitable for performing X-ray absorption experiments (Fig. 1) in the fluorescence mode of detection at the S Kedge $(E \sim 2.5 \mathrm{keV})$. For this purpose, the cell was furnished with two gas manifolds ( 2 and 3 in Fig. 1) to supply the anodic and cathodic sides of the IT-SOFC pellet with $\mathrm{H}_{2}$ and synthetic air, respectively. Windows (1 in Fig. 1 ) being permeable to soft X-rays were installed. Cell components ( 7 in Fig. 1 ) in direct contact with the GDC electrolyte pellet were made from Crofer 22 APU steel to achieve compatible thermal expansion coefficient. Electrical contact was taken with Pt wire and paste (MaTecK). Electrical sealing of steel cell compartments ( 7 in Fig. 1) from current collectors ( 4 and 5 in Fig. 1) was achieved using alumina tubing and glass paste (Schott). X-ray spectroscopy cell was mounted on the heating element (6 in Fig. 1) with temperature precision of $0.1{ }^{\circ} \mathrm{C}$. A security cell with Kapton as X-ray windows was mounted over the SOFC-XAS cell to protect the measurement chamber against sulphur contamination. Amel 7050 Potentiostat with Junior Assist software for data acquisition were used for electrochemical tests. Gas flows were controlled with digital mass flow controllers (Vögtlin Instruments AG, Switzerland). High purity gases $(\geq 99.995 \%)$ were used for testing.

\subsection{Sulphur K-edge spectra}

X-ray absorption near edge structure (XANES) spectra were recorded at the Phoenix beamline of the Swiss Light Source (SLS) at PSI, Switzerland. The source of the X-rays is an elliptical undulator (APPLE II). The beamline optics consist of a focussing mirror (radius $\sim 1.4 \mathrm{~km}$ ), a filter to suppress higher harmonics contributions, a double-crystal monochromator and a Kirkpatrick-Baez mirror system to focus the beam. For the experiments in this study we used the unfocussed beam with a spot size of about $1 \times 1 \mathrm{~mm}$. A double-crystal monochromator equipped with a silicon [111] crystal, and available Bragg angles ranging from 14 to $75^{\circ}$ allow generation monochromatic light in the energy range from 2050 to $8000 \mathrm{eV}$. The end station of the Phoenix beamline is specially designed to host in situ and operando experiments. For the experiments the standard end station was removed and replaced by the aforementioned custom-made operando XAS cell. The cell was surrounded by a safety compartment with Kapton as X-ray transmitting windows and purged constantly with He during operation. The spectra were collected in fluorescence mode using a dispersive Si-drift chamber solid-state detector. The beam energy was calibrated to the $\mathrm{S}$ K-edge $(2.472 \mathrm{keV})$. Spectra were recorded at the $\mathrm{S}$ Kedge within energy range from 2.40 to $3.20 \mathrm{keV}$, while scanning

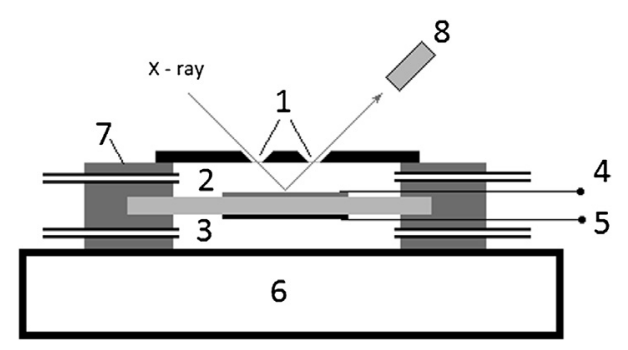

Fig. 1. X-ray absorption spectroscopy cell for operando measurements of IT-SOFC: (1) windows for soft X-ray; (2) anode gas compartment; (3) cathode gas compartment; (4) current collector for anode; (5) current collector for cathode; (6) heating element; (7) cell body with tubing; and (8) fluorescence detector. monochromator and the gap of the undulator synchronously. With the operando XANES spectra, we only recorded a few energy positions around noticeable white-line peaks to obtain discernible peak features between $E=2.466-2.485 \mathrm{keV}$ (comprising all known peak positions) within reasonable data accumulation times (30 min at low $T$ and 60-120 min at high $T$ ).

\subsection{Sulphur speciation with the operando-recorded XANES spectra}

This study focusses on the molecular speciation of sulphur motifs using XANES spectra recorded at the S K-edge under virtually complete steady state conditions at different SOFC temperatures. The establishment of steady state-like conditions was checked by monitoring the integrated fluorescence signal intensity between $E=2.466-2.485 \mathrm{keV}$ as a function of run time. Depending on the SOFC temperature under investigation, the establishment took several hours at start up to 15-30 min at lower temperatures. S K-edge X-ray absorption near edge structure spectroscopy (XANES) at the sulphur K-edge can be used to identify and quantify sulphur atoms exhibiting different oxidation states and molecular structure and those being part of different functional groups [44]. A powerful statistical tool facilitating the speciation analysis is principal component analysis (PCA), allowing estimating the minimal number of independent signal patterns ("principal components", PCs) needed to reproduce a set of data, here the in-total eight operando-recorded S K-edge XANES spectra. The combined principal component analysis-target transformation-linear combination fitting (PCA-TT-LCF) approach has been applied and described by different authors (cf. $[40,45]$ ). The goal of PCA is to find a transformation matrix allowing reproducing a set of data by a minimal number of relevant, independent PCs using Eigenvalue analysis. The higher the eigenvalues, the more important are the associated PCs for reproducing the data set. Importantly, PCA does not relate to any compound spectra nor does it need any other input than a set of non-identical data files. The assignment of a sulphur compound (or sulphur form-representing) spectrum matching best with the characteristics of a given PC is done in a separate step, called target transformation (TT). The PC-representing spectra are then used to determine their amounts with each operando-recorded spectrum by means of least squares sum-based linear combination fitting (LCF). Here, PCA was performed with StatistiXL [46] and with WINXAS version 2.3 [47]. The best-suited sulphur compound spectra ("references") were selected from a 12-fold database using WINXAS using TT. LCF was done using a hand-written program for commercial software (Berkeley Madonna from Kagi Shareware, Berkeley, CA, USA). For these purposes, the fluorescence signal with each operando spectrum was divided (normalised) by the value recorded at $E=2.4845 \mathrm{keV}$, thus, clearly after the highestknown white-line peak-energy position from sulphates [44]. Each normalised operando spectrum was then fitted between $E=2.466$ and $2.485 \mathrm{keV}$ to normalised reference spectra, so that their fitted amounts reflect fractions adding ideally up to unity. The peakenergy position of the sulphate-representing reference spectrum $\left(\mathrm{NiSO}_{4}\right)$ was also adjusted (fitted) in view of its disproportionately high impact on the accuracy with the other, minor, sulphur constituents even in case of a slight mismatch.

\subsection{Thermodynamic phase-predominance diagrams}

To understand the changes in the sulphur oxidation states with the Ni-GDC electrode, we have to take into account thermodynamic as well as kinetic arguments. To estimate thermodynamicallydefined phase transition conditions for the studied system, phase-predominance diagrams were calculated with the HSC software (Outotec Research Oy; Finland) for $\mathrm{Ni}-\mathrm{O}-\mathrm{S}$ and $\mathrm{Ce}-\mathrm{O}-\mathrm{S}$, 
respectively, as functions of the partial pressure of $\mathrm{O}_{2}$ at the anode, $\log \left[p \mathrm{O}_{2}^{\text {anode }}\right]$, temperature, $T$, and, at the sulphur partial pressure used in XAS experiment ( $5 \mathrm{ppm} \mathrm{H}_{2} \mathrm{~S}$ in $\mathrm{H}_{2}$ ). The sulphur partial pressure was introduced with the software as $S_{2}$ with $p S_{2}=1$ / $2 \mathrm{pH}_{2} \mathrm{~S}=2.5 \times 10^{-6}$, because phase-predominance calculations with HSC allows only usage of three different elements. Absence of $\mathrm{H}_{2}$ in the calculations might introduce non-practise-real conditions compared with experiment. The oxygen partial pressure at the anode, characteristic with the operando-recorded XANES spectra, was calculated according to the Nernst equation using experimental temperature, cell voltage, and $\mathrm{pO}_{2}^{\text {cathode }}=0.2$ as input.

\section{Results and discussion}

\subsection{Preliminary electrochemical tests and microstructural characterization}

Preliminary electrochemical tests were carried out using the operando XAS electrochemical cell. Cyclic voltammograms characteristic to SOFC were measured and sulphur poisoning kinetics at constant current conditions and at different $\mathrm{H}_{2} \mathrm{~S}$ concentrations were recorded (Fig. 2). The current density at $600{ }^{\circ} \mathrm{C}$ with supply of hydrogen and synthetic air to the anode and cathode, respectively, at a cell potential $0.6 \mathrm{~V}$ was $50 \mathrm{~mA} \mathrm{~cm}^{-2}$. Relatively low current densities of the studied cell were mainly caused by ohmic losses in supporting electrolyte with relatively high thickness $(670 \mu \mathrm{m})$. The open circuit voltage (OCV) at conditions mentioned above was $0.95 \mathrm{~V}$, which is slightly below theoretical value $(1.138 \mathrm{~V})$, but typical for ceria-based electrolytes. The OCV value did not depend on gas flow rate, which confirms that there was no gas leakage between cathode and anode compartment and potential drop was caused by typical slight electronic current leakage through the GDC membrane. It was electrochemically verified that SOFC single cell was gas-sealed and properly electrically connected. Preliminary sulphur poisoning experiments were carried out at three different $\mathrm{H}_{2} \mathrm{~S}$ concentrations $-0.25 \mathrm{ppm}, 2.5 \mathrm{ppm}$, and, $5 \mathrm{ppm}$ of $\mathrm{H}_{2} \mathrm{~S}$ in $\mathrm{H}_{2}$. The speed of the first rapid poisoning step, which is most likely caused by blocking of TPB, increased with the increase of $\mathrm{H}_{2} \mathrm{~S}$ concentration (Fig. 2). The recovery of electrochemical performance after closing of $\mathrm{H}_{2} \mathrm{~S}$ for 20-30 min was approximately $90 \%$. A smaller drop of the potential and even better electrochemical performance after recovering in short range

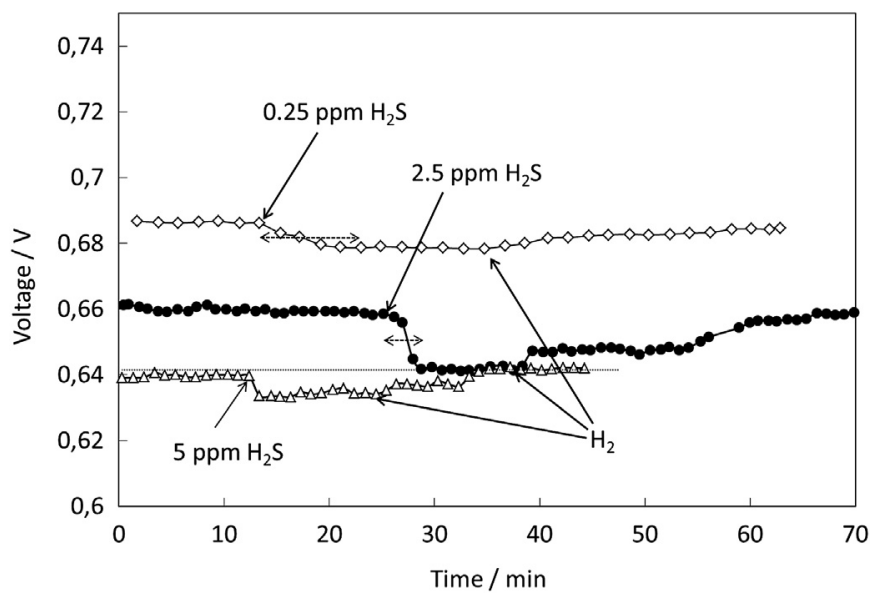

Fig. 2. Dependence of cell voltage on time during sulphur poisoning and regeneration process performed at $T=600{ }^{\circ} \mathrm{C}$ and at constant current condition $\left(50 \mathrm{~mA} \mathrm{~cm}{ }^{-2}\right)$ with $\mathrm{H}_{2} \mathrm{~S}$ concentrations of $0.25,2.5$ and $5 \mathrm{ppm}$ in hydrogen (as indicated in the figure). Dotted horizontal arrows indicate durability of first poisoning step. was achieved after closing of $5 \mathrm{ppm}$ of $\mathrm{H}_{2} \mathrm{~S}$ in hydrogen stream. Similar behaviour of Ni/GDC electrode at low concentrations of $\mathrm{H}_{2} \mathrm{~S}$ and after short contamination with $\mathrm{H}_{2} \mathrm{~S}$ was documented in a comparative study of Ni/YSZ and Ni/GDC by Zhang et al. [21]. This phenomenon was most likely caused by small structural modifications of GDC close to TPB because of interaction with sulphur. In the case of Ni-YSZ, this effect was not observed. Comparison of micrographs for GDC operated in $\mathrm{H}_{2}$ and $\mathrm{H}_{2} \mathrm{~S}$ in Fig. 3 shows microstructural differences expressed as etched interfaces of nickel and GDC in the TPB area after $20 \mathrm{~h}$ poisoning with $5 \mathrm{ppm}$ of $\mathrm{H}_{2} \mathrm{~S}$. We have highlighted three locations in Fig. 3B by the white boxes and seven locations with arrows where we suspect that the etched interfaces originate from the reaction of $\mathrm{Ni}$ with sulphur. Results of preliminary electrochemical experiments confirm that the SOFC single cell installed with the operando XAS cell was indeed working as a fuel cell. Results of sulphur poisoning experiments are in good accordance with previous studies and verify that $\mathrm{H}_{2} \mathrm{~S}$ interacts with $\mathrm{Ni}-\mathrm{GDC}$ catalyst.
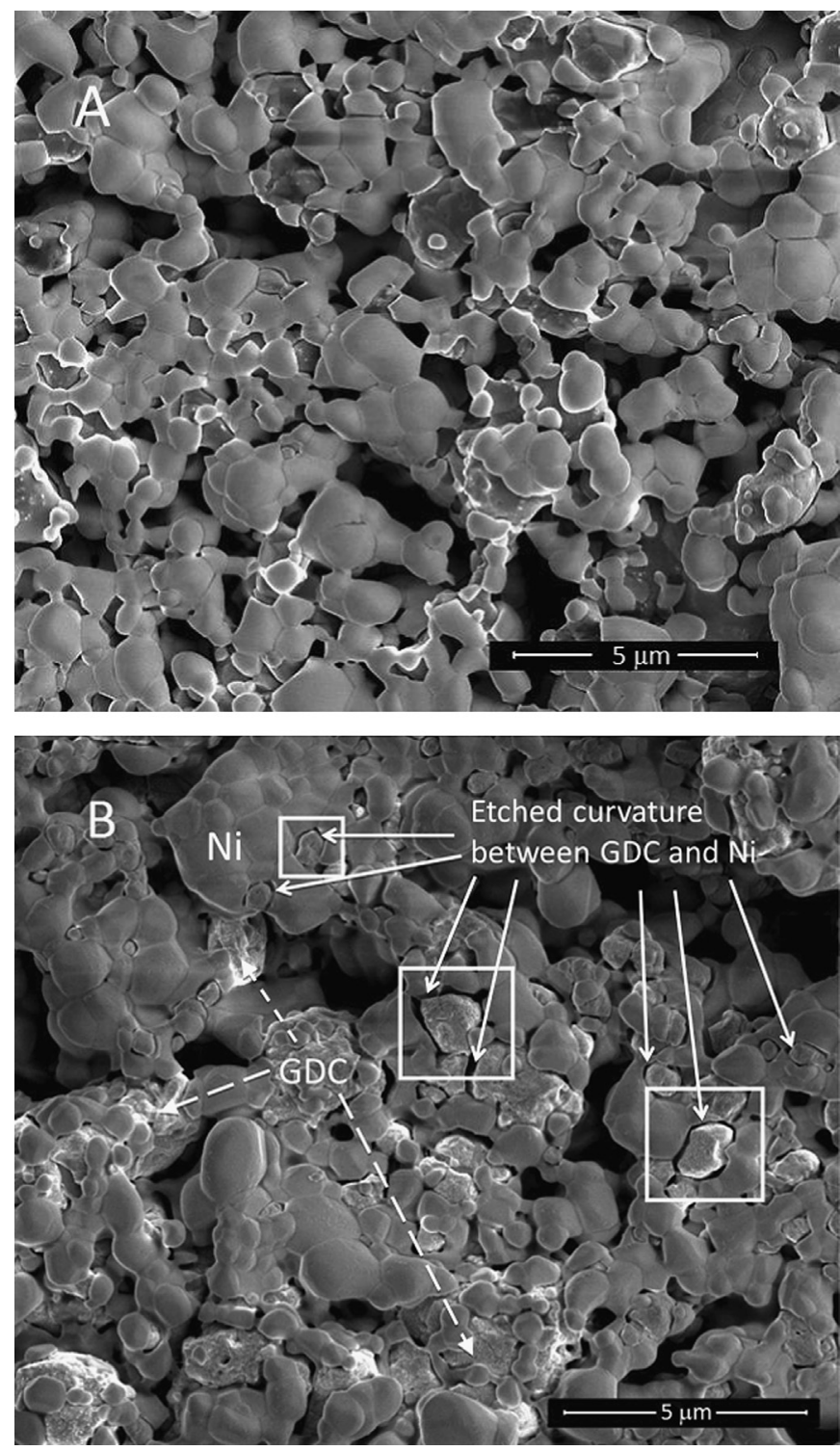

Fig. 3. Post reaction SEM micrograph of Ni-GDC anode after 20 h electrochemical tests at $600{ }^{\circ} \mathrm{C}$ : (a) with hydrogen as a fuel and (b) with hydrogen and $5 \mathrm{ppm} \mathrm{H}_{2} \mathrm{~S}$ as a fuel. Magnification of picture is 7500 times ( $5 \mu \mathrm{m}$ scale bar in the images). 


\subsection{Preliminary operando XANES experiments at the S K-edge}

Spectroscopic measurements were started from higher temperatures at $T=600{ }^{\circ} \mathrm{C}$ with direction to lower temperatures and from lower $\mathrm{H}_{2} \mathrm{~S}$ concentrations ( $0.25 \mathrm{ppm}$ ) to higher (5 ppm) $\mathrm{H}_{2} \mathrm{~S}$ concentrations. With lower $\mathrm{H}_{2} \mathrm{~S}$ concentrations at $T=600{ }^{\circ} \mathrm{C}$, the fluorescence signal from the anode surface was too weak. Also the $5 \mathrm{ppm} \mathrm{H}_{2} \mathrm{~S} / \mathrm{H}_{2}$ gas mixture itself was not detectable with $\mathrm{S}$ K-edge XAS. But, in line with the present lower detection level of the beamline end station, the first detectable signal was recorded with $5 \mathrm{ppm} \mathrm{H}_{2} \mathrm{~S} / \mathrm{H}_{2}$ and at temperature of the studied electrode $T=550{ }^{\circ} \mathrm{C}$, as soon as new sulphur species were formed in concentrations resembling that of (sub)monolayer levels with the anode surface. Spectroscopic data were then collected (Fig. 4), starting from $T=550{ }^{\circ} \mathrm{C}$ with $50 \mathrm{~K}$-steps down to $350{ }^{\circ} \mathrm{C}$. After the scan at $T=350{ }^{\circ} \mathrm{C}$, temperature was raised again without interruption to $T=550{ }^{\circ} \mathrm{C}$ for making the final scan. It was found that the intensity of fluoresence signal increased enormously at lower SOFC temperatures and it revealed significant changes in the shape of the XANES spectra as a function of the irradiated photon energy (Fig. 4). At lower temperatures, the total amount of sulphur compounds residing at (or leaving) the anode surface increased as the absolute intensity of signal increased. This fact is also in good accordance with density functional theory calculations by Wang et al. [27] regarding sulphur surface coverage levels versus bulk sulphur compound formation as a function of temperature and $\mathrm{H}_{2} \mathrm{~S} / \mathrm{H}_{2}$ ratio for the $\mathrm{Ni}-\mathrm{S}$ system, and with the common knowledge on the lifetime of particles at a surface as a function of temperature.

\subsection{Relevant number of sulphur constituents with the operando spectra}

XANES spectra with sulphur form-specific compounds often show a marked first peak ("white-line") at low energy, which is followed by several peak-like features within a modest energy interval $(50-100 \mathrm{eV})$ thereafter. Helpful with a pure sulphur compound or phase is that the white-line energy position increases systematically with increasing sulphur oxidation state (cf. discussion and references in Ref. [40]). But, for mixtures, the "after peak" and white-line positions induced by different sulphur forms may coincide (overlap) with each other. The sulphur compound spectra of importance with the present study are shown with Fig. 5a-h. It is then not possible to estimate the number of different forms just by counting the number of visible peaks with the operando spectra.

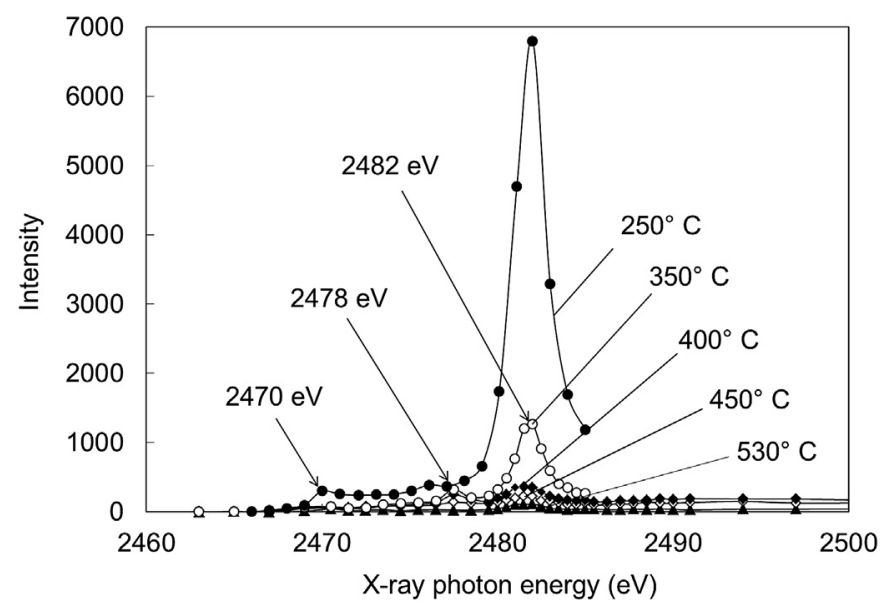

Fig. 4. Dependence of sulphur K-edge XANES spectral intensity on the X-ray photon energy at different measurement temperatures $\left(250^{\circ} \mathrm{C}-530^{\circ} \mathrm{C}\right.$ as shown in the figure) for the Ni-CGO anode in stream of hydrogen with $5 \mathrm{ppm}$ of $\mathrm{H}_{2} \mathrm{~S}$.
Using a purely mathematical analysis with all (8) operando-recorded XANES spectra simultaneously (thus without using any sulphur compound spectrum as reference), principal component analysis (PCA) with StatistiXL [46] indicated that one component (PC-1) was particularly prominent, as it covered (accounted for) about 93\% of data variance (Table 1 ), but it was not very revealing on the possible number of other (minor) principal components, although the operando spectra revealed, at least, three different peaks at about 2470, 2478, and, $2482 \mathrm{eV}$ (see arrows in Fig. 4), resembling closely that of atomically adsorbed elemental sulphur $\left(\sim \mathrm{S}^{0}\right), \mathrm{S}^{4+}$ (as $\mathrm{SO}_{2}$ and/or $\mathrm{SO}_{3}^{2-}$ ), and, $\mathrm{S}^{6+}$ (as $\mathrm{SO}_{3}$ and/or $\mathrm{SO}_{4}^{2-}$ ), respectively (cf. [40] and references cited). Instead, performing PCA with WINXAS [47] was inconclusive, because none of the calculated statistical indicators passed through a minimum value for increasing number of PCs assumed. This outcome can have simple causes, such as too high noise amplitude levels with the spectra (here, $\pm 10 \%$ at best). But, whereas PCA is often found suited for data files in which each file (here, each operando-recorded spectrum) comprises different fingerprints in varying intensities, PCA fails e.g. when one file exhibits a unique fingerprint not found with the other data files. This option is followed further in the next section.

\subsection{Selection of form-representative S K-edge compound spectra}

The assignment of suited sulphur form-representative compound spectra ("references") from a 12-fold, sulphur form-specific, spectral database was done by Target Transformation (TT) using the WINXAS software [47]. Some reference spectra had been measured in previous studies, other compound spectra had been digitised from literature, but corrected and normalised here [40]. The spectral database comprised inorganic (solid $\mathrm{NiS}, \mathrm{NiS}_{2}, \mathrm{Ni}_{3} \mathrm{~S}_{2}, \mathrm{Na}_{2} \mathrm{SO}_{3}$, $\left.\mathrm{NiSO}_{4}\right)$, molecular $\left(\mathrm{S}_{1}, \mathrm{~S}_{2}\right.$ gases $)$, elemental $\left(\mathrm{S}^{0}\right)$, polymeric $\left(\mathrm{S}_{8}\right)$, and aromatic (thiophene) sulphur, and also that of $\mathrm{S}$ atoms and $\mathrm{SO}_{2}$ molecules adsorbed at $\mathrm{Ni}^{0}$ surfaces. With our database, the emphasis lies with ionically bonded sulphur and less with sulphur in covalent bonds (often in connection with carbon atoms), because the presence of $\mathrm{C}$ in the form of $\mathrm{CO}$ had been excluded in the present SOFC experiments for simplicity. Most of the compounds are actually also well-known from other $\mathrm{Ni}$-catalysed heterogeneous processes involving natural (biomass) product gases as feedstock. Using TT, we selected five reference spectra from our database. In decreasing order of importance, the TT procedure indicated $\mathrm{NiSO}_{4} \gg \mathrm{NiS} \sim$ Molecular $\mathrm{S}_{2} \gg \mathrm{Na}_{2} \mathrm{SO}_{3} \sim \mathrm{S}$-atoms-adsorbed-on$\mathrm{Ni}^{0}$-surface ("S-atoms-on- $\mathrm{Ni}^{0}$ ") as the most-suitable sulphur formrepresenting compounds, capable of explaining at least $90 \%$ of data variance with the operando-recorded spectra, thus, well in line with the observed experimental noise within these spectra $( \pm 10 \%)$. For completeness, it must be mentioned that the $\mathrm{S}$ K-edge XANES spectrum of $\mathrm{NiS}$ is practically identical with that of $\mathrm{Ni}_{3} \mathrm{~S}_{2}$, whereas they both $\left(\mathrm{NiS}, \mathrm{Ni}_{3} \mathrm{~S}_{2}\right)$ differ clearly from that of $\mathrm{NiS}_{2}$. On the other hand, we have no reasons to believe that the XANES fingerprints e.g. with $\mathrm{Ce}_{2} \mathrm{O}_{2} \mathrm{~S}$ or $\mathrm{Ce}_{2} \mathrm{~S}_{3}$ will differ much from that of $\mathrm{NiS}$ or $\mathrm{Ni}_{3} \mathrm{~S}_{2}$. Important here is that each reference compound stands for one specific sulphur form (oxidation state, functional group), but not necessarily for the chemical or physical state it had been measured in. For example: $\mathrm{SO}_{2}$ gas and solid $\mathrm{Na}_{2} \mathrm{SO}_{3}$ are both $\mathrm{S}^{4+}$-containing compounds, whereas $\mathrm{SO}_{3}(\mathrm{~g})$ and $\mathrm{NiSO}_{4}(\mathrm{~s})$ each comprise $\mathrm{S}^{6+}$. Linear combination fits reproduced each operando XANES spectrum fairly well, except the one recorded at $T=350{ }^{\circ} \mathrm{C}$ by featuring a sulphur form not present (or hardly seen) with the other spectra. Its fingerprint strikingly resembled that of $\mathrm{SO}_{2}$ adsorbed at $\mathrm{Ni}^{0}$ surfaces $\left(\mathrm{SO}_{2}\right.$-molecules-on-Ni" $\left.{ }^{0 \text { " }}\right)[48,49]$ and it differs noticeably from that of $\mathrm{S}^{4+}$ probed with sulphite salt, such as $\mathrm{Na}_{2} \mathrm{SO}_{3}$. For consistency, the " $\mathrm{SO}_{2}$-molecules-on- $\mathrm{Ni}^{\mathrm{O}}$ " reference spectrum was also fitted with the other operando-recorded spectra. 

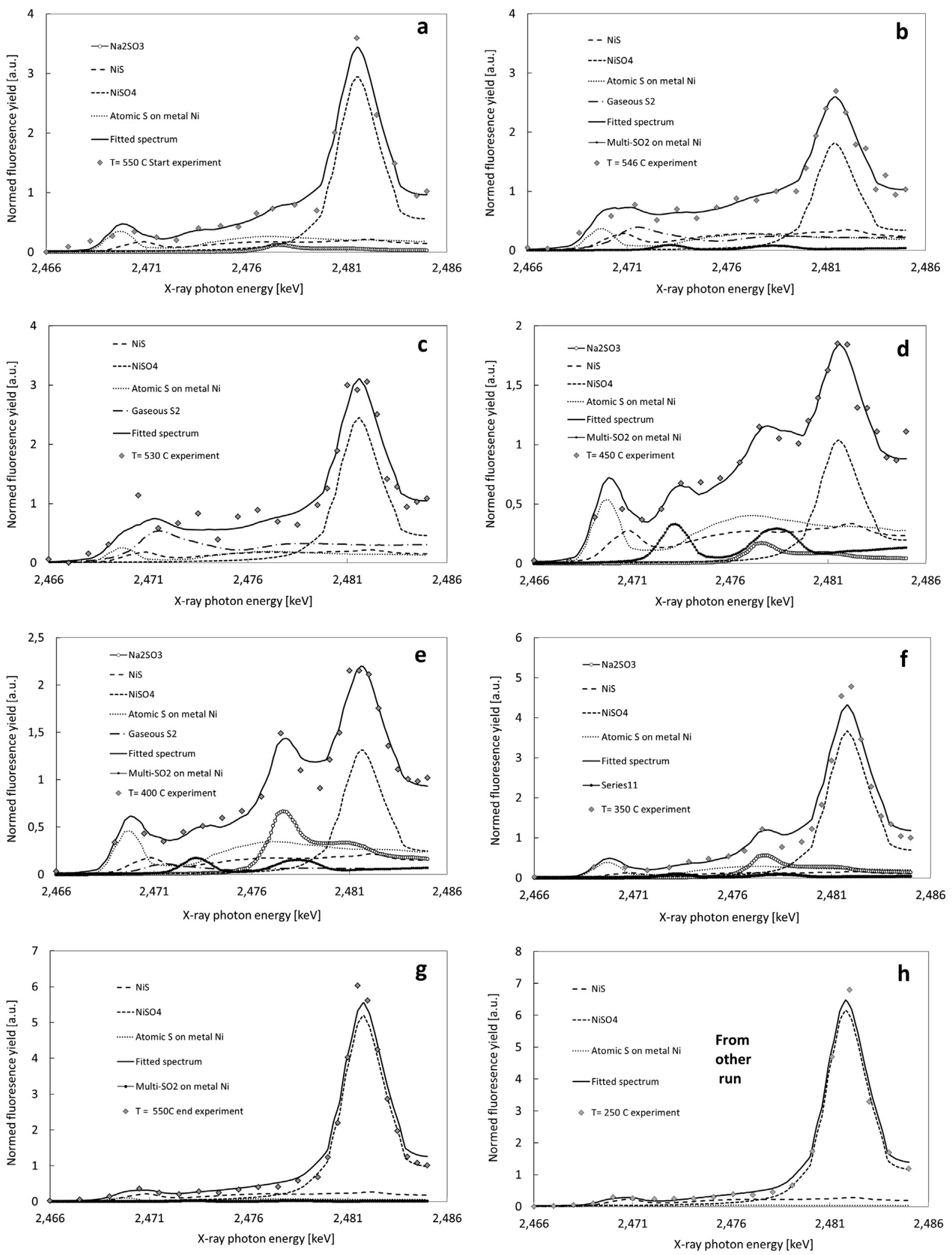

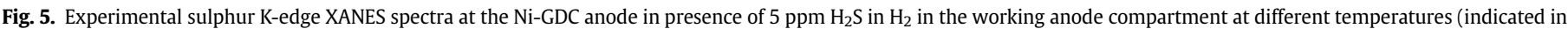
figure). Least square fitting results and model spectra used for fitting are shown as well.

Thus, in total, spectra for six different sulphur containing compounds have been used in the LCF of the operando-recorded XANES spectra. The significant number with the fit results is the sum of the sulphur form-specific fractions, which should be equal to one (1) at ideal conditions (without noise) or $1 \pm 0.1$ within the presence of experimental noise. The latter estimate also implies that fitted fractions clearly falling below 0.1 are potentially disputable as being caused by an experimental noise. 
Table 1

Cumulated variances and eigenvalues from PCA with StatistiXL in case of different number of components used in analysis.

\begin{tabular}{llc}
\hline Number of components & Eigenvalue & Cumulated variance (\%) \\
\hline PC-1 & 7.427 & 92.84 \\
PC-2 & 0.370 & 97.46 \\
PC-3 & 0.106 & 98.78 \\
PC-4 & 0.050 & 99.41 \\
PC-5 & 0.023 & 99.69 \\
PC-6 & 0.016 & 99.88 \\
PC-7 & 0.008 & 99.98 \\
PC-8 & 0.001 & 100.00 \\
\hline
\end{tabular}

\subsection{Data reproduction quality with the operando-recorded XANES spectra}

All operando-recorded S K-edge XANES spectra at Ni-GDC anode characteristic for different temperatures (indicated with the figures) in hydrogen with 5 ppm $\mathrm{H}_{2} \mathrm{~S}$ impurity are shown in Fig. 5, together with the fitted sulphur form-specific constituents and their sum ("fitted spectrum"). The fitted fractions and fitted sulphate peak positions (in terms of shift relative to $2482 \mathrm{eV}$ ) are summarized in Table 2, together with calculated "sum of fractions" and best-fit criterion values ("Residue (\%)"). Note that in Fig. 5 and Table 2, certain sulphur forms $\left(\mathrm{S}^{2-}, \mathrm{S}^{4+}, \mathrm{S}^{6+}\right)$ are not specified regarding chemical or physical state. This was done for the reasons explained in Section 3.4. Focussing on the data reproduction quality, from Table 2 it can be seen that the Residue (\%)-values varied not more than a factor of three $(0.08-0.25 \%)$ between the, respectively, fitted XANES spectra. The sum calculated with the fitted fractions (Table 2) were all close to unity, except with the spectra recorded at $T=350{ }^{\circ} \mathrm{C}$ and $T=250{ }^{\circ} \mathrm{C}$ as well as after reinstalling the SOFC temperature back to $T=550{ }^{\circ} \mathrm{C}$, respectively. These three spectra rendered "sum of fractions" being at least $\sim 25 \%$ larger than the averaged value of $0.96 \pm 0.10$ calculated with the other spectra, thus, they are clearly beyond experimental noise levels ( $\pm 10 \%$ maximally). Another oddity was that their fitted sulphate peak positions deviated systematically nearly $0.2 \mathrm{eV}$ less compared with $\mathrm{NiSO}_{4}$ as reference than the other spectra measured (Table 2).

\subsection{First considerations to the sulphur speciation results}

Fig. 6 shows sulphur form-specific fractions pertaining to the temperature-cycle performed with the functioning SOFC. The run started at $T=550{ }^{\circ} \mathrm{C}$, followed by stepwise lowered residence at different temperatures down to $T=350{ }^{\circ} \mathrm{C}$, and ended after returning back to $T=550{ }^{\circ} \mathrm{C}$. In Fig. 6 , these results are also indicated by their run time order $(1 \rightarrow 7)$ and it also includes speciation results for $T=250{ }^{\circ} \mathrm{C}$ recorded in a foregoing run

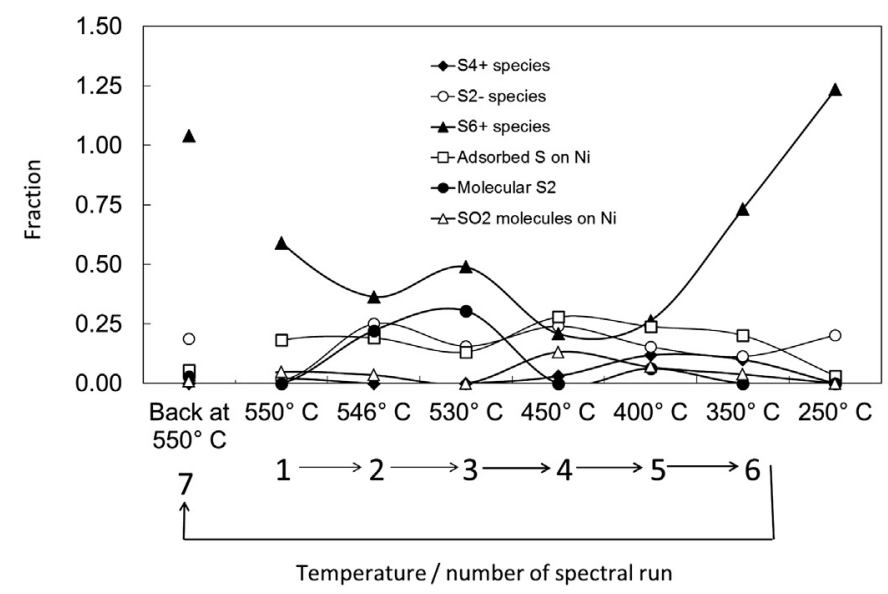

Fig. 6. Sulphur speciation results (fractional composition) as a function of the SOFC operating temperature, characteristic for the Ni-GDC anode, exposed with hydrogen and $5 \mathrm{ppm}$ of $\mathrm{H}_{2} \mathrm{~S}$. Sequence of spectroscopic runs $(1 \rightarrow 7)$ is indicated in the figure. Spectrum at $250{ }^{\circ} \mathrm{C}$ is measured in separate spectral run.

$\left(T=600 \rightarrow 250^{\circ} \mathrm{C}\right)$ with a new, freshly reduced, electrochemical element, labelled “ $T=250^{\circ} \mathrm{C}$ " (another run). From Fig. 6 (Table 2), it follows that only sulphur atoms on metallic $\mathrm{Ni}$ (Atom-S-on- $\mathrm{Ni}^{0}$ ) and $\mathrm{S}^{6+}$ species are noticeable at the beginning and may therefore be related intimately with the modest, reversible, drop in the SOFC performance occurring within minutes after the start of experiment (Section 3.1). Two sulphur forms are joined by the presence of $\mathrm{S}^{2-}$ species and that of molecular $\mathrm{S}_{2}(\mathrm{~g})$ at $T=546{ }^{\circ} \mathrm{C}$. Their run time-delayed appearance indicates that it takes some time (nearly an hour) before reaching steady state-like reaction conditions for a new SOFC electrochemical element. Particularly noticeable thereafter is that the fraction values of $\mathrm{S}^{2-}, \mathrm{S}^{6+}$, and Atom-S-on- $\mathrm{Ni}^{0}$ do not change much between $T=546 \rightarrow 350^{\circ} \mathrm{C}$, except fraction of $S^{6+}$ at $T=350^{\circ} \mathrm{C}$, where it started to increase drastically and grew even more at lower temperatures (" $T=250{ }^{\circ} \mathrm{C}$ (obtained from another run)”). In fact, similarly high values of $S^{6+}$ fraction also persisted shortly after returning back from $T=350 \rightarrow 550{ }^{\circ} \mathrm{C}$. Whatever the cause is, it does not explain the oddities with the sulphateresembling peaks (Section 3.5). In fact, also the molecular $\mathrm{S}_{2}(\mathrm{~g})$ and the $\mathrm{S}^{4+}$ species are of special interest because they appear after each other $\left(\mathrm{S}_{2}(\mathrm{~g})\right.$ within $T=546-530{ }^{\circ} \mathrm{C}$; $\mathrm{S}^{4+}$ within $T=400-$ $350{ }^{\circ} \mathrm{C}$ ), with the rather unique occurrence of " $\mathrm{SO}_{2}$-molecules-at$\mathrm{Ni}^{0}$ “ at $T=450{ }^{\circ} \mathrm{C}$. With respect to $\mathrm{S}_{2}(\mathrm{~g})$, pure thermal decomposition of $\mathrm{H}_{2} \mathrm{~S}$ into $\mathrm{H}_{2}$ and $\mathrm{S}_{2}$ is not very likely, because this process would require substantially higher temperatures $(T>1000 \mathrm{~K})$ than applied here (cf. [50]). Recombination reactions between adsorbed sulphur atoms at the $\mathrm{Ni}^{0}$ surface are also not known for high $\mathrm{S}_{2}(\mathrm{~g})$ output. To better understand the changes in the sulphur oxidation

Table 2

The fitted fractions of constituting sulphur forms, the sum-of-fractions, fitted sulphate peak positions (shift relative to $2482 \mathrm{eV}$ ), and best-fit criterion values (\%Residue).

\begin{tabular}{|c|c|c|c|c|c|c|c|c|}
\hline & $550{ }^{\circ} \mathrm{C}$ start & $546{ }^{\circ} \mathrm{C}$ & $530^{\circ} \mathrm{C}$ & $450{ }^{\circ} \mathrm{C}$ & $400{ }^{\circ} \mathrm{C}$ & $350{ }^{\circ} \mathrm{C}$ & $550{ }^{\circ} \mathrm{C}$ end & $250^{\circ} \mathrm{C}$ \\
\hline$S^{6+}$ species & 0.59 & 0.36 & 0.49 & 0.21 & 0.26 & 0.73 & 1.04 & 1.23 \\
\hline $\mathrm{S}^{4+}$ species & 0.02 & 0.00 & 0.00 & 0.03 & 0.12 & 0.10 & 0.00 & 0.00 \\
\hline Adsorbed $\mathrm{S}$ on $\mathrm{Ni}^{0}$ & 0.18 & 0.19 & 0.13 & 0.28 & 0.24 & 0.20 & 0.05 & 0.03 \\
\hline Molecular $\mathrm{S}_{2}$ & 0.00 & 0.22 & 0.30 & 0.00 & 0.06 & 0.00 & 0.03 & 0.00 \\
\hline $\mathrm{SO}_{2}$ molecules-on $\mathrm{Ni}^{0}$ & 0.05 & 0.04 & 0.00 & 0.13 & 0.07 & 0.04 & 0.01 & 0.00 \\
\hline $\mathrm{S}^{2-}$ species & 0.02 & 0.25 & 0.16 & 0.24 & 0.15 & 0.11 & 0.19 & 0.20 \\
\hline \multicolumn{9}{|l|}{ Related fit results } \\
\hline Sum of fractions & 0.86 & 1.06 & 1.08 & 0.89 & 0.91 & 1.19 & 1.32 & 1.47 \\
\hline Residue (\%) & 0.113 & 0.0989 & 0.214 & 0.064 & 0.097 & 0.262 & 0.250 & 0.192 \\
\hline Shift in sulphate peak position $(\mathrm{eV})^{\mathrm{a}}$ & -0.45 & -0.55 & -0.41 & -0.44 & -0.35 & -0.19 & -0.22 & -0.18 \\
\hline
\end{tabular}

\footnotetext{
${ }^{\text {a }}$ Relative to $\mathrm{NiSO}_{4}$ reference spectrum used in the LCFs.
} 
states at the Ni-GDC electrode, phase-predominance diagrams were calculated for $\mathrm{Ni}-\mathrm{O}-\mathrm{S}$ and $\mathrm{Ce}-\mathrm{O}-\mathrm{S}$, respectively, which will be discussed first before presenting final considerations thereafter.

\subsection{Agreement of spectroscopic results with thermodynamic predictions}

At elevated temperatures, such as $T=550{ }^{\circ} \mathrm{C}$ and $T=450{ }^{\circ} \mathrm{C}$, phase-predominance calculations at experimental $\mathrm{pO}_{2}^{\text {anode }}$ values (Fig. 7) indicated that the formation of $\mathrm{Ni}$ and $\mathrm{Ce}$ sulphatecontaining phases are not thermodynamically favourable, because for the $\mathrm{Ni}-\mathrm{O}-\mathrm{S}$ system, they showed prevailing presence for nickel sulphides, particularly, that of amorphous $\mathrm{NiS}$ or $\mathrm{NiS}_{0.84}$. For the $\mathrm{Ce}-\mathrm{O}-\mathrm{S}$ system, calculations predicted $\mathrm{CeO}_{2}$ to be the predominating phase. The speciation results based on our operando XANES spectra (Fig. 6) showed significant $S^{6+}$-related fractions prevailing with most of the intermediate temperatures investigated from $T=550{ }^{\circ} \mathrm{C}-450{ }^{\circ} \mathrm{C}$. For the interpretation of these experiments, three important aspects should be taken into consideration as well: (i) with $\mathrm{S}$ K-edge XANES spectra, $\mathrm{S}^{6+}$-containing species can either depict the presence of solid sulphate(s) or that of $\mathrm{SO}_{3}$ gas. (ii) Besides $\mathrm{Ni}^{0}$, also ceria has significant affinity to adsorb $\mathrm{SO}_{2}$, leading to $\mathrm{Ce}_{2} \mathrm{O}_{2} \mathrm{~S}$ [51,52], or, to transform $\mathrm{H}_{2} \mathrm{~S}$ into $\mathrm{SO}_{2}$ and/or $\mathrm{SO}_{3}$ gas; cf [53]. (iii) The phase-predominance calculations are made for stoichiometric $\mathrm{CeO}_{2}$ and do not include gadolinia doped ceria (GDC) or partially reduced GDC phases, but non-stoichiometric phases have very different oxygen chemical potentials in crystal lattice [54] and higher reactivity as well as adsorption activity compared with nondoped and non-reduced $\mathrm{CeO}_{2}[32]$. Another important detail is that there was no thermodynamic equilibrium in the studied system at working conditions, and only steady state conditions (flowing gas feeds and flow of oxide ions through the fuel cell membrane) have been established. Different studies proposed and supported experimentally the idea that the release of sulphur from SOFC electrode might take place through the oxidation of sulphur $[10,18,22,23,29]$, which premises the presence of oxidised particles or intermediates on the anode surface.

The coexistence of different sulphur forms as evidenced with the operando-recorded XANES spectra at the S K-edge are unique and they are neither apparent with thermodynamic phasepredominance calculations made here or by other studies $[9,20]$, nor, with density functional theory calculations from Wang et al. [27]. Interestingly, the latter authors made calculations for the $\mathrm{Ni}-\mathrm{S}$ system as a function of $T$ and $\mathrm{H}_{2} \mathrm{~S} / \mathrm{H}_{2}$ ratio, but without oxygen,

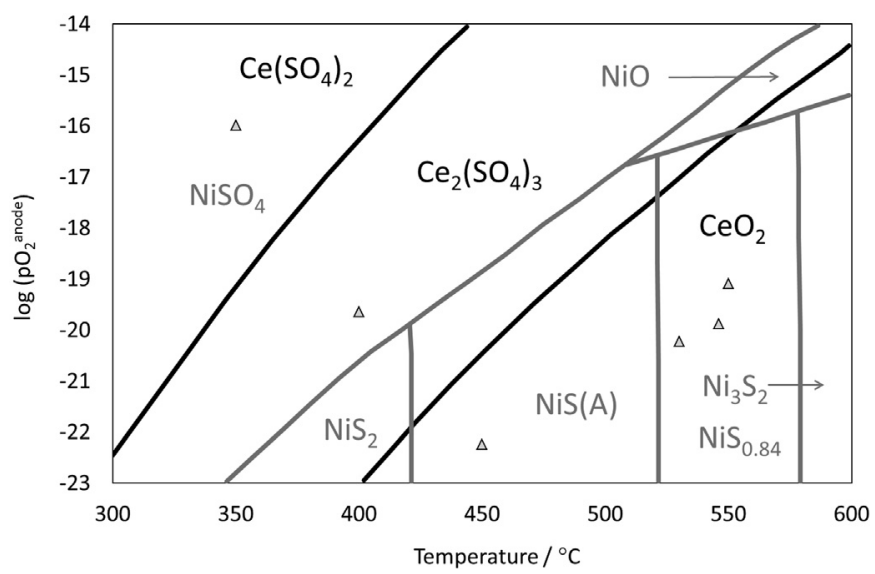

Fig. 7. Overlay of $\mathrm{Ce}-\mathrm{O}-\mathrm{S}$ (black) and $\mathrm{Ni}-\mathrm{O}-\mathrm{S}$ (grey) phase diagrams as a function of temperature and oxygen partial pressure at fixed sulphur partial pressure, $\mathrm{p}_{\mathrm{S} 2}=2.5 \times 10^{-6}$. Triangular points $(\Delta)$ are characteristic for the experimental conditions, where the XAS spectra were measured. showing the existence of an intermediate state between clean $\mathrm{Ni}^{0}$ surfaces and nickel sulphides comprising solely sulphur atoms adsorbed on Ni surfaces. This is also supported by the speciation results presented here.

\subsection{Final considerations}

Considering all previously mentioned information, it is most likely that the $S^{6+}$ signal from $T=550-400{ }^{\circ} \mathrm{C}$ originates prevalently from $\mathrm{SO}_{3}$ particles formed on the GDC surface through the oxidation of adsorbed sulphur particles. This interpretation is supported by the thermodynamic calculations as well as by the methanol synthesis studies using $\mathrm{Pd} / \mathrm{CeO}_{2}$ system with $\mathrm{H}_{2} \mathrm{~S}$ in reducing syngas, leading to formation of $\mathrm{SO}_{3}$ as the highest oxidation product [53]. The $S^{6+}$ fraction drops slightly when going from $T=550-400{ }^{\circ} \mathrm{C}$, most likely because the ion conductivity of GDC membrane and the supply of oxide ions to the TPB and GDC surfaces are decreasing. A relatively large energy shift fitted for the experimentally observed $\mathrm{S}^{6+}$ peak position at these temperatures (Table 2) compared with that for the reference spectrum $\left(\mathrm{NiSO}_{4}\right)$ also confirm that the $\mathrm{S}^{6+}$ signal might originate dominantly from $\mathrm{SO}_{3}$ particles and not from sulphate groups.

At lower temperatures, such as $T=400$ or $350^{\circ} \mathrm{C}$, the formation of sulphate groups is thermodynamically favoured with both, at $\mathrm{Ni}$ and GDC surfaces (Fig. 7). According to the operando-recorded XANES spectra (Fig. 6), we observed an increase of $S^{6+}$ fraction and decrease of the fractions pertaining to less oxidised sulphur forms, which is in good accordance with thermodynamic calculations, because the majority of the $S^{6+}$ signal probed at $T=400{ }^{\circ} \mathrm{C}$ and at $T=350{ }^{\circ} \mathrm{C}$ is most likely caused by formation of sulphate phases. This assumption is supported by the fact that the shift in the experimental sulphate peak position at these lower temperatures compared with $\mathrm{NiSO}_{4}$ spectra is minor (Table 2).

After measuring the spectra, which started at $T=550{ }^{\circ} \mathrm{C}$, and moving towards lower temperatures down to $T=350{ }^{\circ} \mathrm{C}$ (spectral run 1-6 with Fig. 6), the SOFC temperature was set back to $T=550{ }^{\circ} \mathrm{C}$ (spectral run 7) to compare the initial and final spectra at the same temperature. Much higher signal intensity in the final spectrum compared to the one taken at the beginning was detected, which indicates higher concentration of sulphur particles at the anode surface compared to the initial situation at the beginning of the experiment. From sulphur speciation analysis (Table 2), we observed higher sulphate and $S^{2-}$-related fractions for the final state spectrum, but much less Atom-S-on- $\mathrm{Ni}^{0}$ compared with the initial one measured at $T=550{ }^{\circ} \mathrm{C}$, whereas other sulphur forms were absent for both spectra. Strong similarities between fractional composition between initial and final spectrum indicate that the electrode surface, which had been modified at $T=350{ }^{\circ} \mathrm{C}$, needs much longer time to achieve initial situation, except for nonreversible structural changes, as also suggested by recoverage of the SOFC performance up to 90\% within 20-30 min (Section 3.1). However, even when the electrical performance of Ni-GDC is predominantly recovered to initial level with electrochemicallyrelevant TPB-domains, the recovery from chemical modification by sulphur at other, less active domains, could take much longer time.

Finally, the appearance of " $\mathrm{SO}_{2}$-molecules-on- $\mathrm{Ni}^{0}$ " might be related with stronger interaction of sulphur with $\mathrm{Ni}$ being oxidised further in the TPB region at $\mathrm{pO}_{2}^{\text {anode }}$ values prevailing with the working SOFC. However, $\mathrm{NiSO}_{3}$ under less complicated conditions is already unstable at room temperatures $\left(\mathrm{NiSO}_{3}(\mathrm{~s}) \rightarrow \mathrm{NiO}(\mathrm{s})+\right.$ $\mathrm{SO}_{2}(\mathrm{~g})$ [55]), so this could also explain the co-presence of $\mathrm{S}^{4+}$ containing species in the form of $\mathrm{SO}_{2}(\mathrm{~g})$ species at temperatures below which the " $\mathrm{SO}_{2}$-molecules-on- $\mathrm{Ni}^{0}$ " appeared for the first time $\left(T=450{ }^{\circ} \mathrm{C}\right)$, unless suppressed (thermodynamically 
disfavoured) by the formation of $\mathrm{NiSO}_{4}$ occurring at $T \leq 350{ }^{\circ} \mathrm{C}$. In parallel, some $\mathrm{S}^{4+}$ species can also be related to other processes taking place at the GDC electrolyte. As mentioned in Section 3.7, ceria can convert $\mathrm{H}_{2} \mathrm{~S}$ into $\mathrm{SO}_{x}$. The less oxidised form is $\mathrm{SO}_{2}$ and further oxidation gives $\mathrm{SO}_{3}$. One condition of the continuation of such reactions is that the oxygen removed from the ceria $\left(\right.$ as $\left.\mathrm{SO}_{x}\right)$ is compensated. According to Yuchun Ma et al. [53], this can be done, e.g. by adding $\mathrm{O}_{2}$ to the reaction gas, or, more applicable with the SOFC anode, by oxygen ions moving from cathode to the anode surface via the ceria electrolyte lying in between. However, at the lower temperatures investigated here, the $\mathrm{O}^{2-}$-supply is much lower than at temperatures at $T \geq 450{ }^{\circ} \mathrm{C}$ (Fig. 7). Thus, the $\mathrm{SO}_{3}$ formed at high temperatures is restricted to that of $\mathrm{SO}_{2}$ at $T=400$ and $350{ }^{\circ} \mathrm{C}$ along with the formation of $\mathrm{Ce}_{2}\left(\mathrm{SO}_{4}\right)_{3}$, whereas the formation of $\mathrm{SO}_{2}$ vanishes at $T=250{ }^{\circ} \mathrm{C}$, because the formation of $\mathrm{Ce}\left(\mathrm{SO}_{4}\right)_{2}$ prevails thermodynamically. Another explanation for the absence of any $\mathrm{SO}_{2}$-related sulphur form within $T=550 \rightarrow 450{ }^{\circ} \mathrm{C}$ and sudden presence within $T=400 \rightarrow 450{ }^{\circ} \mathrm{C}$ could also be the discontinuation (or disablement) of the $\mathrm{Ce}_{2} \mathrm{O}_{2} \mathrm{~S}$ regeneration reaction with $\mathrm{SO}_{2}$ due to insufficient $\mathrm{O}^{2-}$ supply, because the otherwise co-produced elemental sulphur (and here likely that of molecular $\mathrm{S}_{2}$ ) was no longer detected as soon as the $\mathrm{SO}_{2}$-related forms appeared.

\section{Conclusions}

These first operando SOFC-XAS experiments at the S K-edge revealed formation of several sulphur containing compounds with different sulphur oxidation states $(6+, 4+, 0,2-)$ in parallel by reactions of $\mathrm{H}_{2} \mathrm{~S}$ with the $\mathrm{Ni}-\mathrm{GDC}$ cermet anode. Here, these oxidation states are characteristic for $-\mathrm{SO}_{4}^{2-}$ or $\mathrm{SO}_{3},-\mathrm{SO}_{3}^{2-}$ or $\mathrm{SO}_{2}$ (g), molecular $\mathrm{S}_{2}$ or surface-adsorbed $\mathrm{S}$ atoms, and, $\mathrm{Ni}$ and/or $\mathrm{Ce}$ sulphides, respectively. The dynamics of sulphur oxidation states with the subsequently lowered temperatures town $T=550-350{ }^{\circ} \mathrm{C}$ were monitored and discussed. The " $\mathrm{S}^{6+}$ " fraction was nearly $60 \%$ at the beginning of experiment and decreased to approximately 20$25 \%$ till $T=400{ }^{\circ} \mathrm{C}$, before it increased drastically at lower temperatures, reaching $\sim 90 \%$ at $T=250{ }^{\circ} \mathrm{C}$ (established use in a separate run), where $\mathrm{NiSO}_{4}$ and $\mathrm{Ce}\left(\mathrm{SO}_{4}\right)_{2}$ are thermodynamically favoured. The " $\mathrm{S}$ " species are indicating atomically adsorbed sulphur atoms at the $\mathrm{Ni}^{0}$ surface and that of molecular $\mathrm{S}_{2}(\mathrm{~g})$ formed by redox $\left(\mathrm{Ce}^{3+}, \mathrm{Ce}^{4+}\right)$ reactions of ceria with $\mathrm{H}_{2} \mathrm{~S}$ with $\mathrm{Ce}_{2} \mathrm{O}_{2} \mathrm{~S}$ (" $\mathrm{S}^{2-")}$ ) and $\mathrm{SO}_{x}\left(\right.$ " $\mathrm{S}^{4+}, \mathrm{S}^{6+")}$ as intermediates. Deviations from thermodynamic phase calculations were detected and are likely caused by the differences between assumed equilibrium and real kinetic-controlled steady state conditions prevailing for the SOFC conditions applied, as well as by different reactivity of stoichiometric $\mathrm{CeO}_{2}$ assumed in calculations, and that of partially reduced ceria (GDC) inhibiting redox system based $\left(\mathrm{Ce}^{3+}, \mathrm{Ce}^{4+}\right)$ reactivity with the experiment. From the present experiences, also kinetic information regarding individual sulphur oxidation steps can be accessed, because the time for reaching stable fluorescence signal after changing the SOFC temperature took longer than the shortest data accumulation period practised here ( $\sim 30 \mathrm{~min})$. Developed an operando SOFC-XAS cell is versatile as it also allows studying contamination effects at the air-fed cathode side, including $\mathrm{Cr}$ [56] poisoning and alkaline elements if appropriate X-ray windows for higher oxygen partial pressures are applied. The presented cell allows also to obtain the metal (in the present case $\mathrm{Ni}$ and $\mathrm{Ce}$ ) absorption edges, which may facilitate the identification of $\mathrm{Ni}$ - and $\mathrm{CeO}_{2}$-related reaction products with sulphur. We are confident that the outcome of our initial work will stimulate further operando experiments on SOFC assemblies under real exploitation conditions.

\section{Acknowledgements}

This work was funded by Sciex-NMS program under award number: 10.063 (In-Situ-SOFC-XAS). Partial funding was received from Swiss National Science Foundation, Estonian Science Foundation (Grant number 7791) and Estonian Center of Excellence (Materials for sustainable development). A.B. is grateful for the support from Peter Holtappels and Thomas Graule (Empa), and for financial support from the European Union under Marie Curie project \# 042095 "X-ray and Electrochemical Studies on Solid Oxide Fuel Cells and Related Materials" and FCH JU project \# 256885 “Solid Oxide Fuel Cells - Integrating Degradation Effects into Lifetime Prediction Models", and the Swiss Competence Center for Energy and Mobility (CCEM), contract \# CO 350260. Authors thank Markus Janousch (SLS) for fruitful discussion and other staff at PSI involved at different stages of the project, in particular, Lukas Oberer, Markus Mähr, Daniel Peitz, Peter Hottinger, Eric de Boni, Reto Wetter Maarten Nachtegaal, and Maria Casapu. Authors also thank Thyssen Krupp for providing the high performance steel used to construct the test cell.

The S K-edge spectroscopic measurements were performed on the Phoenix beamline at the Swiss Light Source, Paul Scherrer Institut, Villigen, Switzerland.

\section{References}

[1] D.J.L. Brett, et al., Chem. Soc. Rev. 37 (2008) 1568-1578.

[2] N. Oishi, A. Atkinson, N.P. Brandon, J.A. Kilner, B.C.H. Steele, J. Am. Ceram. Soc. 88 (2005) 1394-1396.

[3] E.D. Wachsman, et al., Science 334 (2011) 935.

[4] Y.B. Kim, et al., Adv. Funct. Mater. 21 (2011) 4684-4690.

[5] F.N. Cayan, M. Zhi, S.R. Pakalapati, I. Celik, N. Wu, R. Gemmen, J. Power Sources 185 (2008) 595-602.

[6] J. Bao, G.N. Krishnan, P. Jayaweera, J. Perez-Mariano, A. Sanjurio, J. Power Sources 193 (2009) 607-616.

[7] G. Nurk, P. Holtappels, R. Figi, J. Wochele, M. Wellinger, A. Braun, T. Graule, J. Power Sources 196 (2011) 3134-3140.

[8] A.I. Marquez, T.R. Ohrn, J.P. Trembly, D.C. Ingram, D.J. Bayless, J. Power Sources 164 (2007) 659-667.

[9] K. Sasaki, et al., J. Electrochem. Soc. 153 (2006) A2023-A2029.

[10] Z. Cheng, et al., J. Power Sources 172 (2007) 688-693.

[11] Y. Matsuzaki, I. Yasuda, Solid State Ionics 132 (2000) 261-269.

[12] S. Zha, Z. Cheng, M. Liu, J. Electrochem. Soc. 154 (2007) B201-B206.

[13] A. Lussier, S. Sofie, J. Dvorak, Y.U. Idzerda, Int. J. Hydrogen Energy 33 (2008) 3945-3951.

[14] Z. Cheng, M. Liu, Solid State Ionics 178 (2007) 925-935.

[15] R.V. Siriwardane, J.A. Poston Jr., E.P. Fisher, Appl. Surf. Sci. 243 (2005) 40-54.

[16] Z. Cheng, S. Zha, M. Liu, J. Power Sources 172 (2007) 688-693.

[17] C.M. Grgicak, J.B. Giorgi, J. Phys. Chem. C 111 (2007) 15446-15455.

[18] N. Lakshminarayanan, U.S. Ozkan, Appl. Catal. A: Gen. 393 (2011) 138-145.

[19] P.V. Aravind, J.P. Ouweltjes, N. Woudstra, G. Rietveld, Electrochem. Solid-State Lett. 11 (2008) B24-B28.

[20] P. Lohsoontorn, D.J.L. Brett, N.P. Brandon, J. Power Sources 175 (2008) 60-67.

[21] L. Zhang, S.P. Jiang, H.Q. He, X. Chen, J. Ma, X.C. Song, J. Hydrogen Energy 35 (2010) 12359-12368.

[22] C. Xu, P. Gansor, J.W. Zondlo, K. Sabolsky, E.M. Sabolsky, J. Electrochem. Soc. 158 (2011) B1405-B1416.

[23] E. Brightman, D.G. Ivey, D.J.L. Brett, N.P. Brandon, J. Power Sources 196 (2011) $7182-7187$.

[24] X.C. Lu, J.H. Zhu, J. Electrochem. Soc. 155 (2008) B1053-B1057.

[25] M. Gong, X. Liu, J. Trembly, C. Johnson, J. Power Sources 168 (2007) 289-298.

[26] H. He, R.J. Gorte, J.M. Vohs, Electrochem. Solid-State Lett. 8 (2005) A279A280.

[27] J. Wang, M. Liu, Electrochem. Commun. 9 (2007) 2212-2217.

[28] T.S. Li, H. Miao, T. Che n, W.G. Wang, C. Xu, J. Electrochem. Soc. 156 (12) (2009) B1383-B1388.

[29] T.S. Li, W.G. Wang, J. Power Sources 196 (2011) 2066-2069.

[30] M. Blaszczyszyn, R. Blaszczyszyn, R. Meclewski, Surf. Sci. 131 (1983) 433-447.

[31] H. Kurokawa, T.Z. Sholklapper, C.P. Jacobson, L.C.D. Jonghe, S.J. Visco, Electrochem. Solid-State Lett. 10 (2007) B135-B138.

[32] H. Devianto, S.P. Yoon, S.W. Nam, J. Han, T.-H. Lim, J. Power Sources 159 (2006) 1147-1152.

[33] A. Braun, et al., J. Power Sources 183 (2008) 564-570.

[34] M. Mehdi Taghiei, Frank E. Huggins, Naresh Shah, Gerald P. Huffman, Energy Fuels 6 (3) (1992) 293-300.

[35] S. Pattanaik, F.E. Huggins, G.P. Huffman, W.P. Linak, C.A. Miller, Environ. Sci. Technol. 41 (2007) 1104-1110. 
[36] H. Dathe, A. Jentys, J.A. Lercher, J. Phys. Chem. B 109 (2005) 21842-21846.

[37] R. Sarangi, S. DeBeer George, D.J. Rudd, R.K. Szilagyi, X. Ribas, C. Rovira, M. Almeida, K.O. Hodgson, B. Hedman, E.I. Solomon, J. Am. Chem. Soc. 129 (8) (2007) 2316-2326.

[38] A. Braun, D. Bayraktar, A.S. Harvey, D. Beckel, J.A. Purton, P. Holtappels, L.J. Gauckler, T. Graule, Appl. Phys. Lett. 94 (2009) 202102.

[39] A. Braun, S. Erat, D. Bayraktar, A. Harvey, T. Graule, Chem. Mater. 24 (8) (2012) $1529-1535$.

[40] R.P.W.J. Struis, T.J. Schildhauer, I. Czekaj, M. Janousch, S.M.A. Biollaz, Chr. Ludwig, Appl. Catal. A: Gen. 362 (2009) 121-128.

[41] E. Lust, R. Küngas, I. Kivi, H. Kurig, P. Möller, E. Anderson, K. Lust, K. Tamm, A. Samusshenko, G. Nurk, Electrochim. Acta 55 (26) (2010) 7669.

[42] I. Kivi, P. Möller, H. Kurig, S. Kallip, G. Nurk, E. Lust, Electrochem. Commun. 10 (2008) $1455-1458$.

[43] St. Hannemann, Ph. Trüssel, M. Casapu, A. Baiker, J.-D. Grunwaldt, E. Welter, P. Haider, J. Synchrotron Radiat. 14 (2007) 345-354.

[44] J. Prietzel, J. Thieme, U. Neuhäusler, J. Susini, I. Kögel-Knabner, Eur. J. Soil Sci. 54 (2003) 423-433.

[45] R.P.W.J. Struis, Chr. Ludwig, T. Barrelet, U. Krähenbühl, H. Rennenberg, Sci. Total. Environ. 403 (2008) 196-206.
[46] StatistiXL, a statistics add-in for Microsoft Excel. Designed by Alan Roberts and Philip Withers. http://www.statistixl.com.

[47] T. Ressler, J. Synchrotron Radiat. 5 (1998) 118-122. WINXAS software.

[48] T. Ohta, T. Yokoyama, S. Terada, A. Imanishi, Y. Kitajamam, Res. Chem. Intermed. 26 (2000) 29-43.

[49] S. Terada, A. Imanishi, T. Yokoyama, Y. Kitajima, T. Ohta, J. Electron. Spectrosc. Relat. Phenom. 80 (1996) 245-248.

[50] R.B. Slimane, F.S. Lau, R.J. Dihu, M. Khinkis, Production of hydrogen by superadiabatic decomposition of hydrogen sulfide, in: Proceedings of the 2002 U.S. DOE Hydrogen Program Review, 2002. NREL/CP-61032405.

[51] Y. Zeng, S. Zhang, F.R. Groves, D.P. Harrison, Chem. Eng. Sci. 54 (1999) 3007.

[52] M. Flytzani-Stephanopoulos, M. Sakbodin, Z. Wang, Science 312 (2006) 1508

[53] Y. Ma, Q. Ge, W. Li, H. Xu, Appl. Catal. B: Environ. 90 (2009) 99-104.

[54] M. Mogensen, N.M. Sammes, G.A. Tompsett, Solid State Ionics 129 (2000) 6394.

[55] Nickel, in: Gmelins Handbuch der Anorganischen Chemie, Verlag Chemie, Weinheim (D), 1966. Systen Nr. 57, Teil B, Lieferung 2.

[56] J.A. Schuler, Chr. Gehrig, Z. Wuillemin, A.J. Schuler, J. Wochele, Chr. Ludwig, A. Hessler-Wyser, J. Van Herle, J. Power Sources 196 (2011) 7225-7231. 